\title{
No Acute Toxicity Tests of Purwoceng (Pimpinella pruatjan Molk.) Ethanolic Extract on Male Albino Rat by Determined Hepatorenal Function Test and Histopathology
}

\author{
Fitranto Arjadi ${ }^{*}$, Dhadhang Wahyu Kurniawan ${ }^{2}$, Yudhi Wibowo ${ }^{3}$, Wahyu Siswandari ${ }^{4}$, Lantip Rujito ${ }^{5}$ \\ 'Departement of Anatomy, Faculty of Medicine, Universitas Jenderal Soedirman Purwokerto 53112 , \\ Indonesia \\ ${ }^{2}$ School of Pharmacy, Faculty of Health Sciences, Universitas Jenderal Soedirman Purwokerto 53113 , \\ Indonesia \\ ${ }^{3}$ Departement of Comunity Medicine, Faculty of Medicine, Universitas Jenderal Soedirman Purwokerto \\ 53112 , Indonesia \\ ${ }^{4}$ Departement of Clinical Pathology, Faculty of Medicine, Universitas Jenderal Soedirman Purwokerto \\ 53112 , Indonesia \\ ${ }^{5}$ Departement of Molecular Biology, Faculty of Medicine, Universitas Jenderal Soedirman Purwokerto \\ 53112 , Indonesia
}

*Corresponding author email: f.arjadi@yahoo.com

Received July 11, 2019; Accepted October 30, 2019; Available online November 30, 2019

\begin{abstract}
Pimpinella pruatjan Molk is a local indegineuos plant speciescommonly used aphrodisiac. This study was performed to analyze the effect of acute administration of purwoceng (Pimpinella pruatian Molk.) roots ethanol extract to liver and kidney histological damage in rats. The study used an experimental approach using post test only with control group design. Rats were randomly divided into five groups; 3 rats in each group. Group A as a control group received aquadest, group B, C, D, and E were given purwoceng roots ethanol extract dose of $5 \mathrm{mg} / \mathrm{kgBW}, 50 \mathrm{mg} / \mathrm{kgBW}, 300$ $\mathrm{mg} / \mathrm{kgBW}$, and $2000 \mathrm{mg} / \mathrm{kgBW}$ respectively.Liver histological damage was assessed by a modification of the Roenigk score, whereas kidney damage was by the semiquantitative scoring of proximal tubular necrosis. UV test was used to quantify the AST and ALT levels, the measurement of blood urea levels was using the Urease-GLDH method, and Jaffe method was used to access the creatinine levels.Kruskal-Wallis test showed that liver and kidney histological parameters were not significantly affected, as well as the blood urea and creatinine levels ( $p>0.05)$. Meanwhile, ALT level was only parameters which showed the significant test $(p<0.05)$ among groups. Study concluded that the liver and kidney histological appearance, AST, blood urea, and creatinine levels in the male albino rat were not significantly affected by acute administration of Purwoceng roots in various doses but the ALT level was significantly affected
\end{abstract}

Keywords: Purwoceng, acute toxicity test, rattus norvegicus

\section{INTRODUCTION}

Purwoceng (Pimpinella pruatian Molk), especially the roots, are used empirically as a herbal medicine to enhance male vitality. They grow endemically in several highlands in Indonesia. This plant is thought to have an androgenic and anabolic effect (Wahyuningrum, Utami, Dhiani, Kumalasari, \& Kusumawardani, 2016). Previous research on animals has proven that the root content of Purwoceng has androgenic effects that can be useful to increase spermatogenesis in the testes, increase sperm count and motility, and have antioxidant effects and increase levels of $\mathrm{LH}$ hormone and testosterone(Taufiqurrachman, 1999). Phytochemical tests show that the roots of Purwoceng contain flavonoid compounds, tannins, coumarin, saponins, sterols, alkaloids, oligosaccharides, eurycomalactone, and amarolinda_(Darwati \& Roostika, 2016).

The active compounds of the phytochemical test results contained in the roots of Purwoceng are xenobiotic compounds that will undergo biotransformation and excretion as well as drugs in general. The rest of the biotransformation of the drug can be toxic to the human body. Liver as the primary organ of drug biotransformation and renal excretion as the primary organ of excretion will be exposed to the residual metabolic, toxins, and microbes that are susceptible to damage (Dixon, Lane, MacPhee, \& Philips, 2014).

Active compounds of purwoceng roots are potentially toxic. Lipophilic compounds such as alkaloids, tannins, and flavonoids can cause damage to body cells, such as hepatocytes and kidneys(Mujeeb, Bajpai, \& Pathak, 2014). The 
damage caused by the active compound is easier to bind to the cells of the body and increases the duration of metabolism and excretion of drugs in the body. Other active compounds such as phenol are secondary metabolites that also can cause toxic effects and irritate body cells. The content of alkaloids is lipophilic so that it can irritate the renal cell membrane(Kyselova, 2011).

The safety of the drug can be illustrated by toxicity test in order to make the drug safe. Acute toxicity test aimed to determine the value of LD50 and toxic effects that appeared on target organs (liver and kidney) within a short period after single oral doses of medication or recurrent doses within 24 hours.

\section{EXPERIMENTAL SECTION \\ Study Design}

The study was an experimental study using post test only with control group with complete randomized design.

\section{Subjects}

The albino rats (Rattus norvegicus) with the characteristics of the male, 8 - 12 weeks old, and weighing of 150 - 200 grams were included. Rats that showed illness and decrease of body weight $>10 \%$ in the acclimatization period were dropped out. Fifteen rats were randomly dividedinto 5 groups (group A, B, C, D, E), contains three rats in each group. Control group (A) was not given any treatment, just like normal rats in general given feed and drink (ad libitum) in the cage, group B, C, D, and $\mathrm{E}$ were orally administered as $0.3 \%$ carboxymethyl cellulose (CMC) suspension in doses of $\mathrm{kg} 5 \mathrm{mg} / \mathrm{kgBW}, 50 \mathrm{mg} / \mathrm{kgBW}, 300 \mathrm{mg} / \mathrm{kgBW}$, and $2000 \mathrm{mg} / \mathrm{kgBW}$ Purwoceng roots ethanol extract once.

\section{Procedure}

The study examined the Purwoceng roots ethanol extract made with repeated maceration method._The dried Purwoceng root is ground to powder and 500 grams of powder produced was then macerated in $96 \%$ ethanol as much as $2500 \mathrm{~mL}$, left to stand for 24 hours, and filtered to produce the first maceration results. The first maceration waste was added with $96 \%$ ethanol as much as $2500 \mathrm{~mL}$, stirred, allowed to stand for 24 hours and filtered to produce the second maceration result. The second maceration waste product was added with $96 \%$ ethanol as much as $2500 \mathrm{~mL}$, stirred and allowed to stand for 24 hours and filtered using a vacuum extractor and produced the third maceration result. The first, second, and third maceration mixture was evaporated on a water bath to evaporate the ethanol content so that pure purwoceng root extract was obtained Experimental rats that have been marked are then put into cages measuring $60 \times 40 \times 35 \mathrm{~cm}$. Experimental rats that have been marked are then put into cages that have been provided by a random method, 3 rats for each cage and acclimatization for 7 days to provide opportunities for adaptation to the environment and nutrition. The feed given to experimental rats was $A D$ $\| ®$ feed and $A Q U A \AA$ mineral water drinks by ad libitum.

A single dose suspension contained with $0.3 \%$ carboxymethyl cellulose (CMC) as a carrier and 5 $\mathrm{mg} / \mathrm{kgBW}, 50 \mathrm{mg} / \mathrm{kgBW}, 300 \mathrm{mg} / \mathrm{kgBW}$, and 2000 $\mathrm{mg} / \mathrm{kgBW}$ ethanol extract of the roots of Purwoceng administered through oral sonde on the first day after the acclimatization process was complete. Observations were made during the first $4 \mathrm{hrs}$ after dosing to determine anysigns of general toxicity (convulsions, tremors, diarrhea, agitation, and coma). Second observation at 24 hours and blood samples were taken using hematocrit pipettes through the orbital sinus. Rats were killed by cervical dislocation method, then the liver and kidney were obtained. Liver and kidney were rinsed by normal saline and fixed in Neutral Buffered Formaline then stained with Hematoxylin-Eosin (HE).

\section{Observation}

The liver cells changes were assessed based on a Modified Roenigk score of 20 hepatocytes per field of view, score 1 was given for normal cells, score 2 for parenchymatous degeneration cells, score 3 for hydropic degeneration cells, and score 4 for necrotizing cells and total score summed up to observations made up to five fields of view (Refs). Kidney damage was observed in 100 proximal tubular structures with 400x magnification and the proximal tubules were defined to be necrotic if there are one of the signs of pyknosis, karyolysis, and karyorrhexis. The scoring was assessed using a semiquantitative scoring system; a score of 0 for a normal histological appearance, a score of 1 for tubular cell degeneration with necrosis which is not significant, score 2 for necrosis $\leq 25 \%$, score 3 for necrosis $26-50 \%$, score 4 for necrosis $51-75 \%$, and a score of 5 for necrosis $>75 \%$ (Hsu, Tsai, Chen, Huang, \& Yen, 2011; Zhang et al., 2008). Measurement of AST and ALT levels was using UV test method, urea content using urease-GLDH method $(\lambda 340 \mathrm{~nm})$ while measurement of creatinine with Jaffe method ( $\lambda 492 \mathrm{~nm}$ ). Normal values of blood urea, creatinine, AST and ALT levels from Integrated Research and Testing Laboratory of Gadjah Mada University were 13.2-29.5 mg/dL, 0.1-0.4 mg/dL, 72.9-127.9 U/l and 44.5-74.9 U/I.ALT. The experiment was conducted in Integrated Research and Testing Laboratory of Gadjah Mada University and data collection was conducted Research Laboratory Medical Faculty Jenderal Soedirman University

\section{Statistical Analysis}

Validity and reliability test between observers were done using the Kappa test.The univariate analysis consists of the mean and standard deviation of 
observations in each group. The normality and bivariate analysis were performed by normality test results and the types of data obtained for each research variable.

\section{Ethical Clearance}

All procedures have been approved by the Health Research Ethics Committee (MHREC), Faculty of Medicine, Padjajaran University (Approval letter reference

\section{4/UN.6.C13.2/KEPK/PN/2015).}

\section{RESULTS AND DISCUSSION}

An acute median lethal dose $\left(L_{50}\right)$ is a statistically derived amount of a substance that can be expected to cause death in $50 \%$ of the animals when given by a specified route as a single dose and the animals observed for a specified time period of time and no dead rats were found at 4 hours and 24 post administration of ethanol extract, so no $L_{50}$ levels were determined in the acute administration of purwoceng root ethanol extract.

\section{Liver Histology}

The morphology of rat's hepar is very similar to humans, multilobulated organ, on the most cranial and the right side of the abdominal cavity, in the intrathoracic portion and had contact with the diaphragm. Normal liver histologic features might be seen more in Group A since the shape and size of the cells were still uniform, with the nuclei of cells still round and centered, as well as visible widened sinusoids. P. parenchymatous degeneration could be seen from hepatocytes which larger than normal size with reddish granules cytoplasm as a result of protein build-up. Hydropic degeneration could be seen from hepatocytes which larger than normal size, but there was a vacuole in a clear cytoplasm. Degeneration can be seen throughout the group. Necrosis can be seen from the nuclei that change the form of pyknotic, karyorrhexis, and karyolysis. Pyknotic is a solid, intriguing portrayal, the karyorrhexis is the nuclei that break into fragments, while the karyolysis is the depiction of the fading cell nucleus (Figure 1).

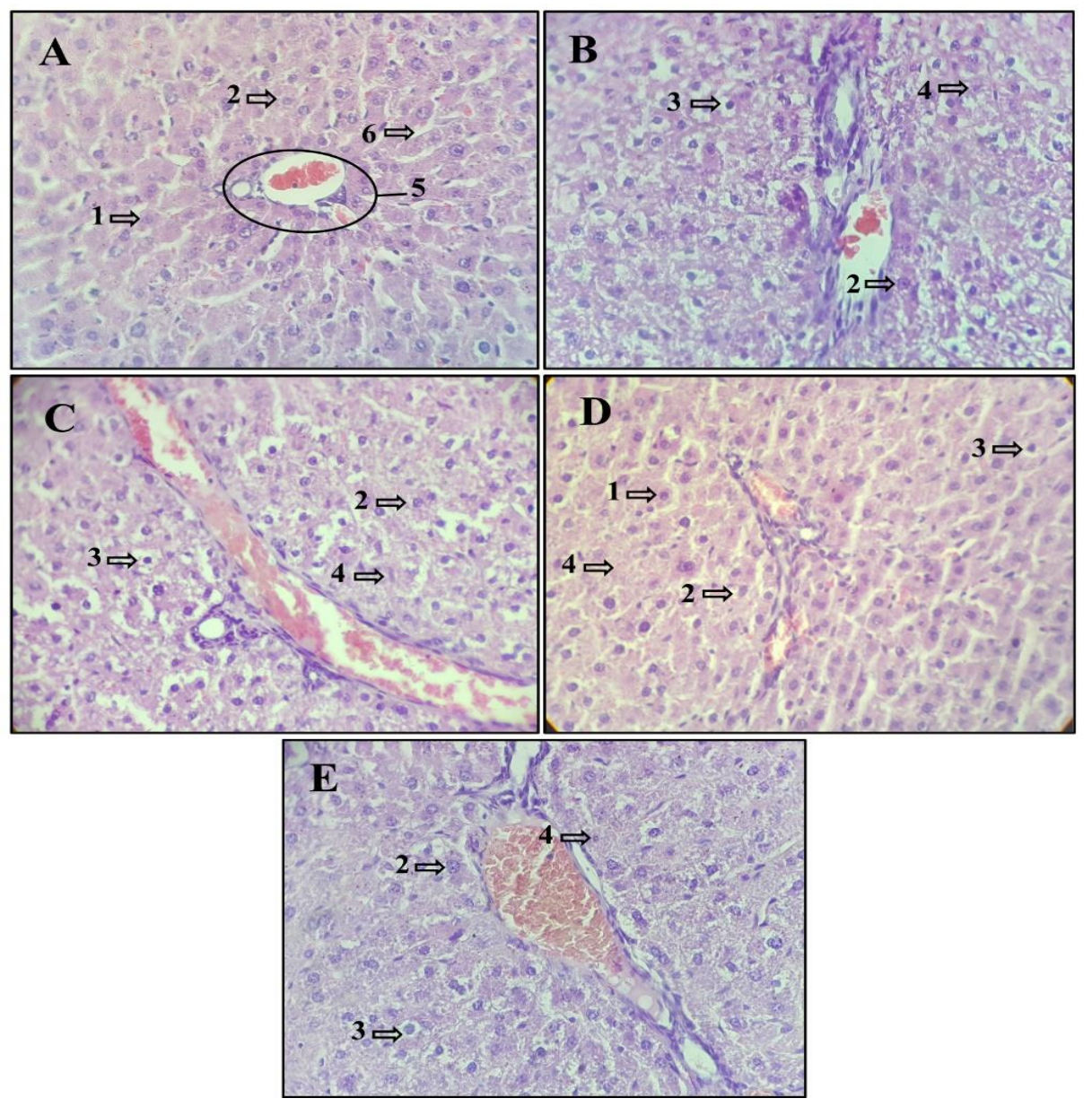

Figure 1. Liver histological appearance in male albino rat (Rattus norvegicus). Group A: control group; Group B: Purwoceng roots extract dose of $5 \mathrm{mg} / \mathrm{KgBW}$; Group C: 50 mg/KgBW; Group D : 300 mg/KgBW; Group E : 2000 mg/KgBW. (1) normal hepatocytes; (2) parenchymal degeneration; (3) hydropic degeneration; (4) necrosis; (5) portal area; (6) sinusoid. Hematoxylin-eosin (HE) staining; 400x magnification 


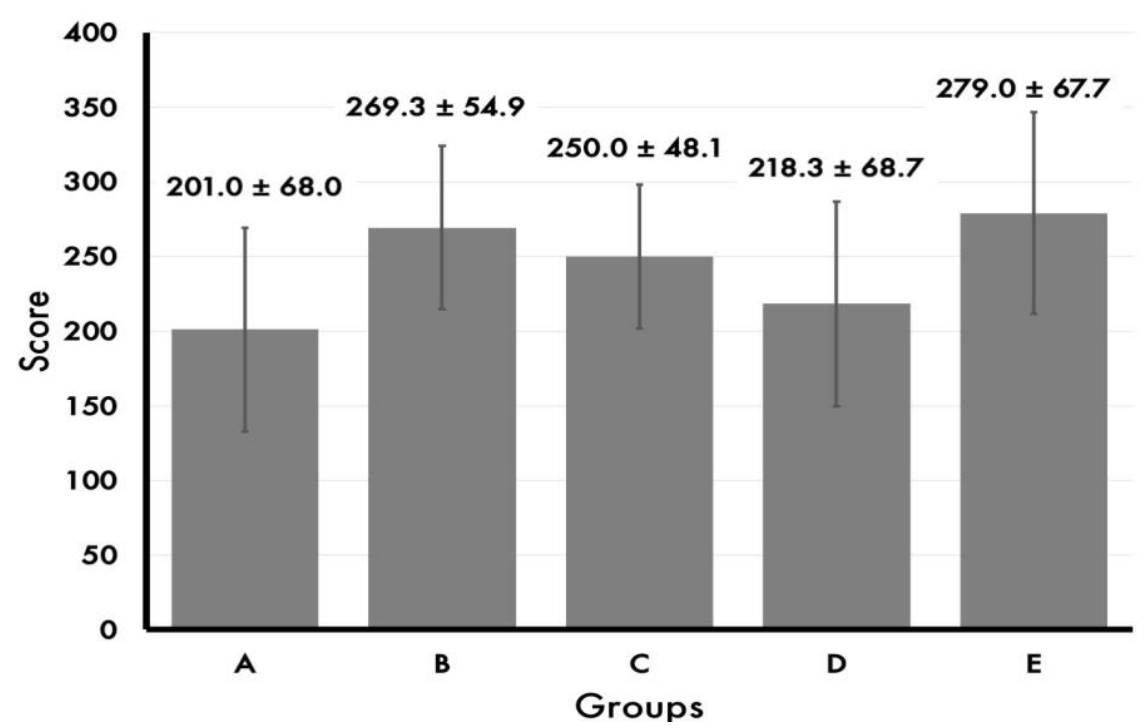

Figure 2. Mean of total Roenigk score. Group A: control group; Group B :Purwoceng roots extract dose of $5 \mathrm{mg} / \mathrm{KgBW}$; Group C : $50 \mathrm{mg} / \mathrm{KgBW}$; Group D : $300 \mathrm{mg} / \mathrm{KgBW}$; Group $E: 2000 \mathrm{mg} / \mathrm{KgBW}$.
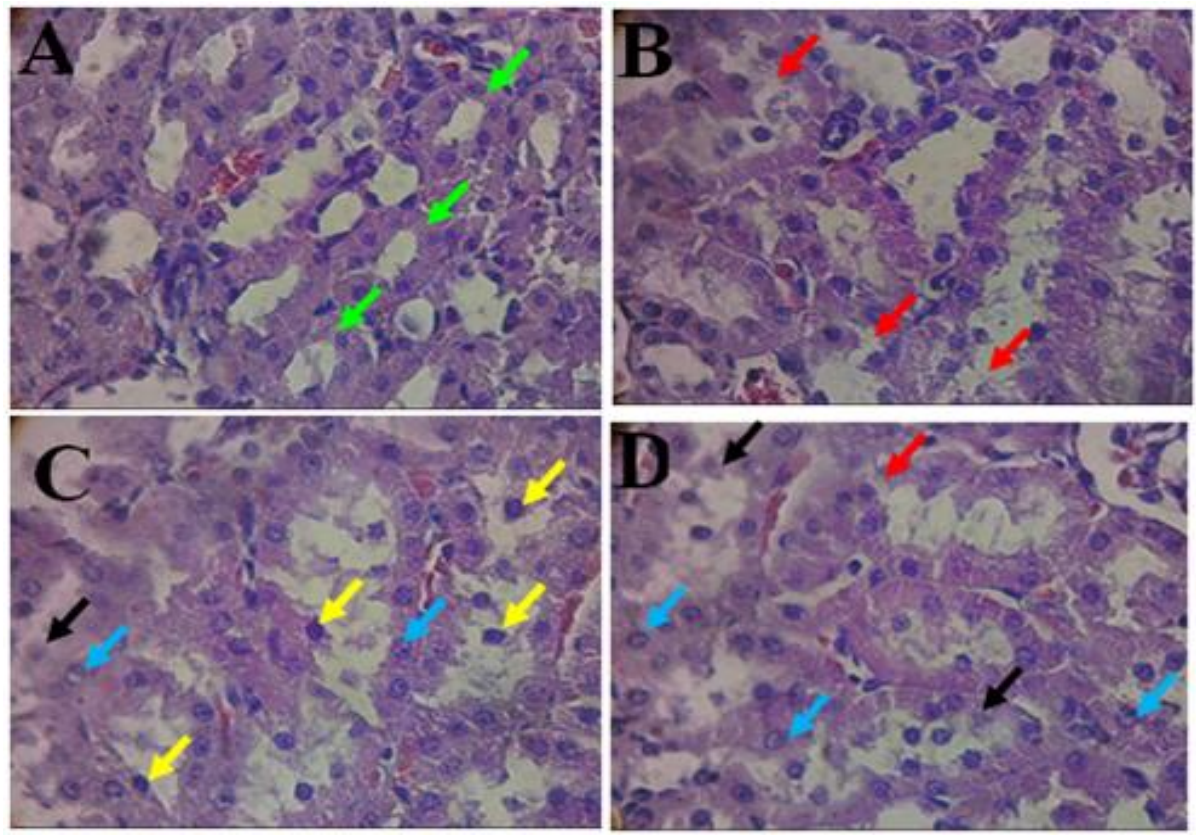

Figure 3. Proximal tubular of kidney histological appearances. Group A : control group; group B:Purwoceng roots extract dose of $5 \mathrm{mg} / \mathrm{KgBW}$; group C : $50 \mathrm{mg} / \mathrm{KgBW}$; group D : $300 \mathrm{mg} / \mathrm{KgBW}$; group E : $2000 \mathrm{mg} / \mathrm{KgBW}$.Green arrow: normal tubular cells; yellow arrow : pyknotic cells; blue arrow: karyorrhexis; black arrow: karyolisis. HematoxylinEosin(HE) staining, 400x magnification

Table 1. Mean of Proximal Tubular Necrosis in Male Albino Rat (Rattus norvegicus)

\begin{tabular}{lc}
\hline \multicolumn{1}{c}{ Group } & $\begin{array}{c}\text { Necrosis Score } \\
\text { (Mean } \pm \text { SD) }\end{array}$ \\
\hline A (control group) & $4.3 \pm 0.5$ \\
B (purwoceng roots extract dose of $5 \mathrm{mg} / \mathrm{kgBW}$ ) & $4.6 \pm 0.5$ \\
C (purwoceng roots extract dose of $50 \mathrm{mg} / \mathrm{kgBW}$ ) & $4.6 \pm 0.5$ \\
D (purwoceng roots extract dose of $300 \mathrm{mg} / \mathrm{kgBW}$ ) & $4.6 \pm 0.5$ \\
E (purwoceng roots extract dose of $2000 \mathrm{mg} / \mathrm{kgBW}$ ) & $4.6 \pm 0.5$ \\
\hline
\end{tabular}


The highest total mean score of modified Roenigk scoring system results was found in group $E$, followed by $B, C$, and $D$ as shown in Figure 2. The result of the Kruskal-Wallis test showed that $p=0.363$ ( $p>$ 0.05 ) showed that there was no significant difference in histological liver damage between groups. The data analysis was continued with Mann-Whitney test to see the difference of change between Group $D$ and the other group, while for Group A, B, C, and E the follow-up analysis was done by using $T$ independent test. Mann-Whitney and $T$ independent test results obtained $p>0.05$ so that differences in liver histological appearance changes proved to have no significant differences between groups.

Liver histological appearances of the control group (A) show various Roenigk scores, and damage from parenchymatous degeneration to necrosis due to factors such as biological factors, chemical factors, heredity factors, and environmental factors were found. Environmental factors have been controlled by providing the same cage and situation. The situation is controlled by maintaining temperature, humidity, and air circulation, as well as the cage that was always cleaned every day. The same food intake was also given throughout the group, but the amount of feed, feed history, and drinking history in the rats of this study was unknown. The amount of feed intake that is lacking for three days according to a study can cause minor damage to the liver tissue (Bohdan et al., 2017).

The treatment in this study was carried out for 24 hours by administering a single dose drug orally to see the organ response to the dose given in a short time. Damage to hepatocytes in this study showed no significant differences between the groups because liver regeneration can occur perfectly on days 2, 4 and eight post-hepatic resections, so that irreversible damage to hepatocytes could occur same as in Nigella sativa (Kumar et al., 2016)

\section{Kidney Histology}

Figure 3 (A) shows a picture of the normal proximal tubule characterized by a slightly oval tubule and intact tubular cells, the lumen visibly dirty by the presence of a brush border, as well as a normal nucleus. Figure 3B, 3C, and 3D shows necrosisappearance in the form pyknosis, karyolysis, karyorrhexis, as well as cell fragmentation. Pyknotic nuclei appearance can be seen in Figure $3 \mathrm{C}$ as shown by the yellow arrow. The blue arrow in Figure 3C and 3D shows a karyorrhexis nuclei appearance. Meanwhile karyolysis shows the fading nuclei, and the karyolysis appearance is shown in Figure 3C and 3D as well by the black arrow. Another tubular necrosis parameter is the presence of cell fragmentation that was characterized by the detachment of one cell with another cell. The cell fragmentation was shown in Figure $3 \mathrm{~B}$ by the red arrow, ere the most common findings of necrosis feature, whereas pyknosis was the most rarely found in almost every microscopic slides in each group. Microscopic slide of group A (controls) shows a lot of the normal tubular features, but tubular necrosis also present. Most tubular necrosis feature is present in group C, and dominated by cell fragmentation appearances compared to other necrosis parameters. The mean percentage of proximal tubular necrosis of each treatment group is shown in Table 1. The mean of group A (control) group necrosis is the lowest of all group (63.50 \pm 11.95$)$ and the group treatment means were higher compared to group A (control). Group $C$ had the highest mean $(84.13 \pm 8.17)$, followed by $E(83.66$ \pm 11.45), $\mathrm{D}(80.63 \pm 5.11)$, and $\mathrm{B}(75.06 \pm$ $18,81)$. The result of the Kruskal-Wallis test showed that there was no significant difference of mean proximal tubular necrosis score between five research groups. The $p$-value $=0,904$ so it was not statistically significant ( $>0,05)$. Acute administration of purwoceng root ethanol extract in male albino rats at doses of $5 \mathrm{mg} / \mathrm{kgBW}, 50$ $\mathrm{mg} / \mathrm{kgBW}, 300 \mathrm{mg} / \mathrm{kgBW}$, and $2000 \mathrm{mg} / \mathrm{kgBW}$ did not result in statistically significant renal impairments.

The content of alkaloids, phenols, saponins, tannins, and flavonoids in Purwoceng are thought to have the potentially causing kidney damage due to its lipophilic and cytotoxic properties. However, in this study post-treatment renal damage was not significant. For various reasons, one of them is probably because the substances at the root of purwoceng are not toxic, or are only mildly toxic. Other studies have shown that purwoceng active compounds may be protective for the kidney. Bioflavonoids can inhibit oxidative stress by reaction with scavenger radical lipid peroxyl when lipid peroxidation occurs. It may increase scavenger activity of free radicals, anti-inflammatory, and apoptotic effects, as well as contribute to kidney protection(Havakhah et al., 2014).

The phenolic component of the ketone and flavonoid derivatives in ginger can increase antioxidant enzymes in mice with renal failure. A previous study suggests that the alkaloid of the Chinese Huang lean crop (Coptidis rhizoma) has a protective effect on tubular epithelial cells with the ONOO-scavenger mechanism, protects against DNA damage, and controls the cell cycle (Yokozawa, Satoh, Cho, Kashiwada, \& Ikeshiro, 2010). The study also suggested that flavonoid and polyphenol content as herbal medicine, can prevent degeneration of renal cells and reduce the severity of renal tubular damage in the dose of $200 \mathrm{mg} / \mathrm{kgBW}$ Wistar albino rat (Yokozawa et al., 2010).

In this study, group C (50 mg / $\mathrm{kgBW})$ had a higher mean percentage of necrosis $(84.13 \pm 8.17)$, followed by $D(300 \mathrm{mg} / \mathrm{kgBW})(80.63 \pm 5.11)$ and $E$ $(2000 \mathrm{mg} / \mathrm{kgBW}) \quad(83.66 \pm 11.45)$. The greater damage in group $C$ may be influenced by the effects 
of flavonoids and polyphenols that can prevent and reduce the severity of renal tubular necrosis so that the mean percentage of tubular necrosis in group $D$ and $\mathrm{E}$ were lower than $\mathrm{C}$. Another possibility is due to the administration of purwoceng root extract which is still in safe dose and short span of time. In a study of Areca catechu containing alkaloids, administration of $1000 \mathrm{mg} / \mathrm{kgBW}$ of mice for 14 consecutive days resulted in focal necrosis, granular degeneration of tubular epithelial cells, and congestion in albino rats' kidney (Nasri et al., 2013), it suggests that the dose and time span of administration may also affect the onset of toxic effects.

Purwoceng as a traditional aphrodisiac drug is expected to be male infertility therapy because it can modulate the release of testosterone hormones if administered over a long period. Thus, a purwoceng safety profile is needed for longer-term use whereas acute toxicity test is only performed within a short span of time so it is necessary to test the next stage of toxicity, i.e subchronic toxicity test. Subchronic toxicity tests may provide information about the toxic effects of undetectable substances on acute toxicity tests, as well as to study the cumulative effects and reversibility effects of the substances contained in the drug under test (Darwati \& Roostika, 2016).

Tubular necrosis cannot be determined solely by histologic observation and renal health assessment is necessary with other parameters before the study, for example, urinalysis examination. It can also be caused by the animal feeds containing coccidiostat as an antiparasitic for animals. Coccidiostat has an ionophore content which is a lipophilic agent that activates cation transport between cell membranes, thus causing tubular cell electrolyte disturbance, resulting in damage to tubular cell membranes (Vandenberge, 2012). To maintain the homogenity of the control group, we exclude the rats which showed renal histological abnormality for the final analysis.

\section{AST and ALT Levels}

The AST and ALT levels from mean above normal was seen in Group D (76.27 $\pm 3.27 \mathrm{U} / \mathrm{I})$. The highest AST mean was Group E (121.53 $\pm 16.31 \mathrm{U}$ ( I), followed by group C (109.23 \pm 7,95 U / I), group $B(108.46 \pm 12.41 \mathrm{U} / \mathrm{I})$, group $\mathrm{D}(102.36 \pm$ $7.46 \mathrm{U} / \mathrm{I})$, and the smallest was the control group (99.06 $\pm 8,1 \cup /$ I). The highest ALT mean was Group D (76.27 $\pm 3.27 \mathrm{U} / \mathrm{I})$, and lowest mean was seen in group $A(56.5 \pm 4.18 \mathrm{U} / \mathrm{I})$. The ALT mean of group $D$ was followed by group $C(64.1 \pm 4.76 \mathrm{U}$ / I), group B (59.87 $\pm 10.64 \mathrm{U} / \mathrm{I})$, and group $E$ (59.13 $\pm 9.95 U / I)$. Bivariate analysis used One Way ANOVA was obtained at AST $p$-value $=0,604$ which showed no significant mean difference between AST data group $(p>0,05)$. One Way ANOVA analysis on ALT data obtain $p=0,033$ ( $p$ $<0,05)$, which means there are at least two data groups having significant mean differences and the bivariate data of ALT was then tested by Bonferroni post hoc and found that there was a significant mean difference between group $A$ and group $D$.

Purwoceng root ethanol extracts consist of alkaloids, tannins, flavonoids, saponins, triterpenoids, phenols, glucose, and vitamin C (Rostiana, Haryudin, Aisyah, \& Dadi, 2015).Lipophilic compounds such as alkaloids, flavonoids, saponins, and tannins can break the liver by damaging the cell membrane and increasing membrane permeability resulting in AST and ALT levels more higher. Tannins, vitamin C, flavonoids, saponins, and phenols also have a hepatoprotective effect with its role as an antioxidant (Mujeeb et al., 2014). The highest mean of AST levels is Group E (2000 mg/kgBW) with $121.53 \pm 16.31 \mathrm{U} / \mathrm{I}$ that is mean hepatocyte damage and the higher AST levels can also occur if there is damage to the heart, muscle, brain, and kidney so it is not specific.Increased AST levels within normal limits may also be due to other than hepatotoxic effects because Purwoceng root ethanol extract is also hepatoprotective. Administration of other plants containing alkaloids, flavonoids, triterpenoid and phenol also showed increased AST results but still within normal limits (Novik et al., 2017).

ALT values are more specific to indicate acute hepatocyte damage as the most of these enzymes are found in cytosol hepatocytes, so the levels of this enzyme higher when the hepatocyte membrane damage (Novik et al., 2017). The highest mean of ALT was found in group $D(76.27 \pm 3.27 \mathrm{U} / \mathrm{I})$, slightly increased than the normal value showed that hepatic dysfunction as a result of enzyme biosynthesis and decreased membrane permeability. Liver damage may occur due to direct exposure to toxic substances during the process of detoxification products metabolites and xenobiotic compounds (Singh, Cho, \& Upadhyay, 2015).

Mean of ALT levels decreased at higher doses, i.e in group $E(59.13 \pm 9.95 \mathrm{U} / \mathrm{I})$. It is possible at higher doses of purwoceng root ethanol extract to show more hepatoprotective effects. Purwoceng root ethanol extract contains phenols that neutralize residual reactions of free radicals and flavonoids that can break down reactive oxygen species (ROS) thereby increasing antioxidant activity in the body.Administration of Dendrobium ovatum extract containing flavonoids, alkaloids, triterpenoids, glycosides, and steroids showed the low ALT levels in the highest dose treatment group (400 mg / kgBW) compared to the lower dose group (Ganapaty, Ramaiah, Yasaswini, \& Nuthakki, Harikrishnareddy, 2013).

The results of this study did not show significant differences in urea and creatinine levels since the active substances in purwoceng have not been toxic in the acute period. Active substances that enter the body are still responded by the cells to reduce its 
impact, and the cells will adapt or make improvements so that the kidneys have not shown more effects on treatment for 24 hours. Other causes may be caused by factors such as biological factors, chemical factors, heredity factors and environmental factors. Environmental factors have been controlled by the cage conditioning, light, humidity, temperature, air circulation, cleanliness of the same cage. The cage was cleaned daily. The humidity and the temperature were checked every day. The same ingredients of the feeds were given to all groups. Drinking water was provided to all groups in equal quantities, but the amount of drinking water intake for each rat was unknown. Acute dehydration may increase blood urea levels, indicating an elevated urea level in the renal medulla due to vasopressin which increases urea reabsorption.

\section{Blood urea and Creatinine Levels.}

The highest mean of urea levels was found in group $D(31.53 \mathrm{mg} / \mathrm{dL}$ ), and the lowest was group $A(25.27 \mathrm{mg} / \mathrm{dL})$. The mean urea levels of group $A$, $B$ and $E$ were not significantly different and tended to be lower than the mean urea levels in group $C$ and $D$, and the mean of urea of group treatments (group $B, C, D$, and $E$ ) were not significantly different from the control group (group A).

The lowest mean of creatinine level was found in group $A(0.267 \mathrm{mg} / \mathrm{dL})$, and the highest was in group $E(0.330 \mathrm{mg} / \mathrm{dL})$. Treatment groups (group $B$, $C, D$, and $E$ ) had higher creatinine levels compared with group $A$ (control group) but they were still within normal limits of creatinine levels. The bivariate analysis with Kruskal-Wallis test resulted in $\mathrm{p}=$ 0.555 on urea of experimental animals, while the $p$ value $=0.206$ at creatinine level. The analysis was continued with the Mann-Whitney post hoc test and the result is a $p>0.05$ which shows significant differences in both urea and creatinine levels.

The alkaloids, glycosides, tannins, stigmasterols $(1.10 \%)$ and sitosterols (1.09\%) contained in the same purwoceng root as those contained in the extract of Ficus religiosa $L$ had curative and protective effect on renal function (both in biochemical parameters and histopathological features) (Ma'mun, 2006). Other herbal extracts such as Feijoa sellowiana that have high levels of phenol and flavonoids significantly increase the levels of urea and creatinine because they have an effect on different cells (Karami et al., 2014). Flavonoids, polyphenols, and alkaloids in Butea monosperma have nephroprotective activity as evidenced by the administration of Butea monosperma ethanol extract showed decrease in rat urea content, flavonoids work as nephroprotective properties by inhibiting oxidative stress and when reactive metabolites which can bind and consume glutathione are arrested by flavonoids, then glutathione levels in the kidney increases (Achyut dan Mulukuri, 2014).
The results of this study did not show significant differences in urea and creatinine levels since the active substances in purwoceng have not been toxic in the acute period. Active substances that enter the body are still responded by the cells to reduce its impact, and the cells will adapt or make improvements so that the kidneys have not shown more effects on treatment for 24 hours (Priyanto, 2009). Other causes may be caused by factors such as biological factors, chemical factors, heredity factors and environmental factors. Environmental factors have been controlled by the cage conditioning, light, humidity, temperature, air circulation, cleanliness of the same cage. The cage was cleaned daily. the humidity and the temperature were checked every day. The same ingredients of the feeds were given to all groups. Drinking water was provided to all groups in equal quantities, but the amount of drinking water intake for each rat was unknown. Acute dehydration may increase blood urea levels, indicating an elevated urea level in the renal medulla due to vasopressin which increases urea reabsorption.

\section{CONCLUSIONS}

Acute administration of Purwoceng roots ethanol extract in various doses was not significantly damaged the liver and kidney histological appearance, not significantly increased the levels of AST, blood urea, and creatinine in the male albino rats (Rattus norvegicus) but significantly affected the ALT level so there is still a possibility a damage in the liver cells because ALT is more specific than AST

\section{ACKNOWLEDGEMENTS}

The authors are sincerely thanks to Ministry of Research, Technology and Higher Education of the Republic of Indonesia, Jenderal Soedirman University for funding, Integrated Research and Testing Laboratory of Gadjah Mada University for providing the facilities to carry out this study, and Medical Health Research Ethics Committee (MHREC), Faculty of Medicine, Padjajaran University for the ethical clearance.

\section{REFERENCES}

Achmadi, P. (2011). Kajian androgenik ekstrak etanol akar purwoceng (Pimpinela alpina KDS) terhadap kineria reproduksi tikus putih (Rattus norvegicus) betina dara. Institut Pertanian Bogor.

Achyut, D., \& Mulukuri, S. 2014. Flavonoids in kidney protection. World Journal of Pharmacy and Pharmaceutical Sciences, 4(3): 362-382

Bohdan, M., Iryn, I., Andri, L., \& Alexander, S. (2017). Antioxidant Enzyme activity and lipid peroxidation in rat liver exposed to celecoxib and lansoprazole under epinephrine-induced stress. Journal of Applied Pharmaceutical 
Science, https://doi.org/10.7324/JAPS.2017.71013

Darwati, I., \& Roostika, I. (2016). Status of research in purwoceng (Pimpinella alpina Molk.) In Indonesia. Buletin Plasma Nutfah; 12(1), p915.(https://doi.org/10.21082/blpn.v12n1.200 6.

Dixon, J., Lane, K., MacPhee, I., \& Philips, B. (2014). Xenobiotic Metabolism: The effect of acute kidney injury on non-renal drug clearance and hepatic drug metabolism. International Journal of Molecular Sciences, 15(2), 2538-2553. https://doi.org/10.3390/ijms 15022538

Doostdar, H., Burke, M. D., \& Mayer, R. T. (2000). Bioflavonoids: selective substrates and inhibitors for cytochrome P450 CYP1A and CYP1B1. Toxicology, 144(1), 31-38. https://doi.org/https://doi.org/10.1016/S030 0-483X(99)00215-2

Ganapaty, S., Ramaiah, M., Yasaswini, K., \& Nuthakki, V.K Harikrishnareddy, D. (2013). Quantitative phytochemical estimation and evaluation of hepatoprotective activity of methanolic extract of Dendrobium ovatum (L.) Kraenzl. whole plant against $\mathrm{CCl} 4$ Induced Hepatatoxicity. Journal of Pharmacognosy and Phytochemistry, 2(3), 113-118.

Havakhah, S., Sadeghnia, H. R., Hajzadeh, M.-A.-R., Mohammadian Roshan, N., Shafiee, S., Hosseinzadeh, H., ... Khajavi Rad, A. (2014). Effect of Nigella sativa on ischemia-reperfusion induced rat kidney damage. Iranian Journal of Basic Medical Sciences, 17(12), 986-992. https://doi.org/10.22038/ijbms.2015.3856

Hsu, Y.-W., Tsai, C.-F., Chen, W.-K., Huang, C.-F., \& Yen, C.-C. (2011). A subacute toxicity evaluation of green tea (Camellia sinensis) extract in mice. Food and Chemical Toxicology, 49(10), 2624-2630. https://doi.org/https://doi.org/10.1016/i.fct.2 011.07 .007

Jujo, K., Minami, Y., Haruki, S., Matsue, Y., Shimazaki, K., Kadowaki, H., ... Hagiwara, N. (2017). Persistent high blood urea nitrogen level is associated with increased risk of cardiovascular events in patients with acute heart failure. Esc Heart Failure, 4(4), 545-553. https://doi.org/10.1002/ehf2.12188

Karami, M., Nokabadi, F.K., Ebrahimzadeh, M.A., \& Naghshvar, F. 2014. Nephroprotective effects of Feijoa sellowiana leaves extract on renal injury induced by acute dose of ecstasy (MDMA) in mice. Iranian Journal of Basic Medical Sciences 17(1):69-72

Kyselova, Z. (2011). Toxicological aspects of the use of phenolic compounds in disease prevention. Interdisciplinary Toxicology, 4(4), 173-183. https://doi.org/10.2478/v10102-011-0027-5

Madrigal-Santillán, E., Madrigal-Bujaidar, E.,
Álvarez-González, I., Sumaya-Martínez, M. T., Gutiérrez-Salinas, J., Bautista, M., ... MoralesGonzález, J. A. (2014). Review of natural products with hepatoprotective effects. World Journal of Gastroenterology: WJG, 20(40), 14787-14804.

https://doi.org/10.3748/wig.v20.i40.14787

Ma'mun, S. S., F. Manoi, B. S., Sembiring, T., Sukmasari, A. G., Tjitjah, F., \& Kustiwa, D. (2006). Teknik pembuatan simplisia dan ekstrak purwoceng. Laporan Pelaksanaan Penelitian Tanaman Obat dan Aromatik : 314 $-324$.

Mujeeb, F., Bajpai, P., \& Pathak, N. (2014). Phytochemical evaluation, antimicrobial activity, and determination of bioactive components from leaves of Aegle marmelos. BioMed Research International, 2014, 497606. https://doi.org/10.1155/2014/497606

Nasri, H., Nematbakhsh, M., Ghobadi, S., Ansari, R., Shahinfard, N., \& Rafieian-kopaei, M. (2013). Preventive and curative effects of ginger extract against histopathologic changes of gentamicin-induced tubular toxicity in rats. International Journal of Preventive Medicine, 4(3), 316-321. Retrieved from http://www.ncbi.nlm.nih.gov/pmc/articles/PM C3634170/

Novik, E. I., Dwyer, J., Morelli, J. K., Parekh, A., Cho, C., Pludwinski, E., ... Jayyosi, Z. (2017). Longenduring primary hepatocyte-based cocultures improve prediction of hepatotoxicity. Toxicology and Applied Pharmacology, 336, 20-30.

https://doi.org/https://doi.org/10.1016/j.taap .2017 .09 .013

Priyanto. 2009. Toksikologi, mekanisme, terapi, antidotum dan penilaian risiko. Jakarta: Leskonfi

Rostiana, O., Haryudin, W., Aisyah, S., \& Dadi, D. (2013). Observation of Morphology, Production and The Quality of Porwoceng. Departemen Pertanian Indonesia, Jakarta.

Singh, D., Cho, W. C., \& Upadhyay, G. (2015). drug-induced liver toxicity and prevention by herbal antioxidants: an overview. Frontiers in Physiology, 6, 363. https://doi.org/10.3389/fphys.2015.00363.

Taufiqqurrachman. (1999). Effect of Pimpinella alpina Molk (purwoceng) and eurycoma longifolia root extract. (stake of the earth) against increased testosterone, Ih and fsh levels and differences in increase in sprague dawley mice. Program Pascasarjana Universitas Diponegoro.

Teng, H., Chen, M., Zou, A., Jiang, H., Han, J., Sun, L., ... Liv, J. (2016). Hepatoprotective effects of licochalcone $b$ on carbon tetrachlorideinduced liver toxicity in mice. Iranian Journal of 
Basic Medical Sciences, 19(8), 910-915. Retrieved from http://www.ncbi.nlm.nih.gov/ pmc/articles/PMC5048128/

Vandenberge, V. (2012). Transfer of crosscontamination levels of coccidiostats, antibiotics and anthelmintics from feed to poultry matrices. Ghent University. Faculty of Veterinary Medicine.

Wahyuningrum, R., Utami, P. I., Dhiani, B. A., Kumalasari, M., \& Kusumawardani, R. S. (2016). Screening of potential free radicals scavenger and antibacterial activities of purwoceng (Pimpinella alpina Molk). Tropical Life Sciences Research, 27 (supp 1), 161-166. https://doi.org/10.21315/tlsr2016.27.3.22

Yokozawa, T., Satoh, A., Cho, E. J., Kashiwada, Y., \&
Ikeshiro, Y. (2010). Protective role of coptidis rhizoma alkaloids against peroxynitriteinduced damage to renal tubular epithelial cells. Journal of Pharmacy and Pharmacology, 57(3), 367-374. https://doi.org/10.1211/ 0022357055470

Zhang, J., Brown, R. P., Shaw, M., Vaidya, V. S., Zhou, Y., Espandiari, P., Goering, P. L. (2008). Immunolocalization of Kim-1, RPA-1, and RPA2 in kidney of gentamicin-, mercury-, or chromium-treated rats: relationship to renal distributions of iNOS and nitrotyrosine. Toxicologic Pathology, 36(3), 397-409. https://doi.org/10.1177/0192623308315832 